\title{
Injustices faced by children during the COVID-19 pandemic and crucial next steps
}

\author{
Sydney Campbell ${ }^{1}$. Franco A. Carnevale ${ }^{2}$
}

Received: 10 August 2020 / Accepted: 24 August 2020 / Published online: 3 September 2020

(C) The Canadian Public Health Association 2020

Dear Editor, At present, data regarding SARS-CoV-2 impacts on children and youth (henceforth: young people) seem promising. Young people tend to be infected less frequently and, for those who are infected, the outcomes seem better than adult counterparts (Patel forthcoming 2020). However, statements of this type undermine the complex lives of young people and, by extension, the multifaceted impacts that young people are facing due to the COVID-19 pandemic and related preventive measures. These impacts span psychosocial, behavioural, and physical divides (Chanchlani et al. 2020) and are heightened for those who face socio-economic and/or racial marginalization (Van Lancker and Parolin 2020; Suleman et al. 2020) and those with pre-existing conditions (Wong et al. 2020). Positioning young people as mere "germ spreaders" ignores the diverse interests and voices of young people, and the particular ways they have been harmed throughout this pandemic.

As researchers and policymakers have started examining these impacts, ethical analyses have been mostly absent from reported evidence. Justice provides a sound ethical framework for examining harms faced by young people by analyzing the unjust ways: (i) impacts specific to young people have been handled in policy and practice (i.e., a form of substantive injustice, or injustice resulting from unfair/disproportionate outcomes of decisions that are not morally justified (Miller 2017)) or (ii) young people's voices and perspectives have been disregarded in pandemic policies (i.e., a form of procedural injustice, or injustice related to the process by which

Sydney Campbell

sydney.campbell@mail.utoronto.ca

1 Institute of Health Policy, Management \& Evaluation, University of Toronto, 155 College St, 4th Floor, Toronto, ON M5T 3M6, Canada

2 McGill University, 680 Sherbrooke West, \#1800, Montreal, Quebec H3A 0G4, Canada burdens and benefits are distributed (Miller 2017)). Overall, young people are seen as capable enough to deal with many of the issues they have faced, without sufficient support, but too incapable to contribute to policy discussions, pushing their perspectives to the periphery. Advances in childhood ethics predict these outcomes, challenging the ways young people are often viewed as moral objects by calling for opportunities for young people to participate at a policy level and be repositioned to active moral agents (Carnevale et al. 2020).

Based on this justice lens, we put forward the following calls for urgent change in policy and practice:

- Organizations, institutions, and governments should develop policies and practices to meaningfully engage young people as active contributors in pandemic policy planning deliberations;

- Research related to investigating the (positive and negative) impacts of COVID-19 on young people, in rich ways, should be undertaken using participatory methods (where possible) and deserves governmental funding;

- Governments should devote more resources to ensuring the rights and welfare of young people remain at the forefront of all pandemic discussions (e.g., creating a Children's Commissioner and meaningfully relying on their input);

- Community organizations and teams that have worked with young people during the pandemic should contribute briefs to ensure these experiences are heard in relevant levels of government; and

- The media should prioritize the voices and experiences of young people and their families to ensure they are not overlooked.

As analyses and pandemic planning continue, we call on stakeholders and those in positions of authority to recognize and take necessary steps to redress the injustices faced by young people. Active engagement of young people in these settings is a vitally important action that ought to be promoted. 


\section{Compliance with ethical standards}

Conflict of interest The authors declare that they have no conflict of interest.

\section{References}

Carnevale, F.A., Collin-Vézina, D., Macdonald, M.E., Ménard, J.F., Talwar, V., \& Van Praagh, S. (2020). Childhood Ethics: An ontological advancement for childhood studies. Children \& Society. https://doi.org/10.1111/chso.12406.

Chanchlani, N., Buchanan, F., \& Gill, P.J. (2020). Addressing the indirect effects of COVID-19 on the health of children and young people. Canadian Medical Association Journal, 192(32), E921E927. https://doi.org/10.1503/cmaj.201008.

Miller, D. (2017). Justice. The Stanford Encyclopedia of Philosophy. https://plato.stanford.edu/archives/fall2017/entries/justice/. Accessed 25 Jun 2020.
Patel, N. (Forthcoming, 2020). Pediatric COVID-10: Systematic review of the literature. American Journal of Otolaryngology, 41(5). https://doi.org/10.1016/j.amjoto.2020.102573.

Suleman, S., Ratnani, Y., Loock, C., Stockley, K., Bennett, S., \& Jetty, R. et al. (2020). What paediatricians can do to support children and youth during the COVID-19 pandemic. Practice Point. Canadian Paediatric Society. https:/www.cps.ca/en/documents/position/ what-paediatricians-can-do-to-support-children-and-youth-duringthe-covid-19. Accessed 02 Aug 2020.

Van Lancker, W., \& Parolin, Z. (2020). COVID-19, school closures, and child poverty: A social crisis in the making. Lancet Public Health, 5(5), E243-E244. https://doi.org/10.1016/S2468-2667(20)30084-0.

Wong, C. A., Ming, D., Maslow, G., \& Gifford, E. J. (2020). Mitigating the impacts of the COVID-19 pandemic response on at-risk children. Pediatrics, 146(1), e20200973. https://doi.org/10.1542/peds. 2020-0973.

Publisher's note Springer Nature remains neutral with regard to jurisdictional claims in published maps and institutional affiliations. 